\title{
Seni atau Meme: Segi Artistik dan Strategis "Komik MS Paint Demi Kehidupan Beragama yang Tentram"
}

\author{
Jevon Jeremy \\ Program Studi Penciptaan Seni DKV, Fakultas Penciptaan dan Pengkajian Seni. \\ Program Pascasarjana Institut Seni Indonesia, Yogyakarta. \\ Email: jevonjeremy@gmail.com
}

\begin{abstract}
Abstrak
"Komik MS Paint Demi Kehidupan Beragama yang Tentram”lahir sebagai komik dengan kualitas artistik yang cenderung kacau dan tidak proporsional. Ia digambar dengan sebuah media gratis yang cenderung murahan dan tidak mudah untuk digunakan. Dalam ironisme itu, Komik MS Paint juga menghadirkan candaan ala meme di internet. Metode penciptaan dari komik ini, serta contoh-contoh dari kenyataan yang terjadi disekitar Komik MS Paint, akan menjadi jawaban tentang segi artistik yang tak kasat mata dan segi strategis menghadapi masyarakat yang haus akan kebaruan setiap harinya. Penelitian ini akan dikaji menggunakan idiom-idiom postmodernisme.
\end{abstract}

Kata kunci: Komik, MS Paint, Seni, Meme, Posmodernisme.

\begin{abstract}
"Komik MS Paint Demi Kehidupan Beragama yang Tentram" are made as comics with a chaotic and disproportional artistic quality. It was drawn using free software, which made it look cheap and hard to use. Further than that irony, Komik MS Paint also brings Internet memes as jokes. The creation method of this comic and phenomenon happened regarding this material object answers for hidden artistic and strategic values against the society's expectations of discoveries every day. This research is conducted using Postmodernism Idioms.
\end{abstract}

Keywords: Comic, MS Paint, Art, Meme, Postmodernism.

\section{Pendahuluan}

Hampir tidak ada anak muda dari generasi $\mathrm{Z}$ yang tidak pernah mencoba menggunakan MS Paint, sebuah aplikasi menggambar yang disediakan secara cuma-cuma oleh sistem operasi Microsoft Windows. MS Paint telah menjadi media mencipta objek visual, mulai dari gambar sederhana sampai meme yang beredar di Internet. Rage Memememe populer yang dibuat dengan MS Paintsudah ada sejak tahun 2008, sampai saat ini masih populer digunakan di Indonesia oleh laman seperti Meme Comic Indonesia, Meme Rage Comic Indonesia dan lain-lain. Namun MS Paint tidak tergolong lazim digunakan untuk membuat komik yang "sungguhan", dalam arti bukan meme komik; di lain sisi, komik Indonesia memiliki perkembangan yang berbeda dengan meme komik.

Komik di Indonesia sudah ada sejak lama, bahkan untuk mengatakan bahwa relief-relief yang ada pada candi seperti di Candi Prambanan memiliki muatan cerita dalam visual terjukstaposisi (McCloud, 1993) juga dapat membenarkan secara teknis bahwa budaya komik di Indonesia memang cukup sudah berumur. Dalam perjalanannya, komik Indonesia tidak memiliki gaya yang khas. Pada masa paling populernya sebelum abad 21, komik Indonesia berkiblat pada gaya gambar komik barat dengan tema superhero dan lakonlakon pewayangan seperti Mahabharata dan Ramayana. Setelah mati suri beberapa tahun lantaran tergantikan oleh komik Jepang (manga), Industri komik Indonesia memulai pergerakannya pada tahun 2010 dengan hadirnya Koloni Gramedia, majalah Re:On, platform webkomik, dan lainlain. Hingga kini komik Indonesia mengalami perkembangan pesat bersamaan dengan adanya media sosial dan kehidupan online. Termasuk dalam gerakan komik Indie yang kini menjadi mudah dipromosikan dan diakses lewat internet, yaitu media sosial.

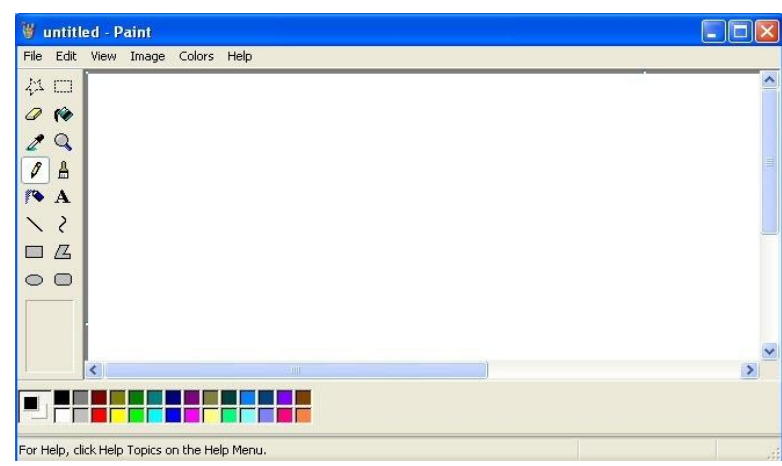

Gambar 1. Tampilan dari MS Paint 


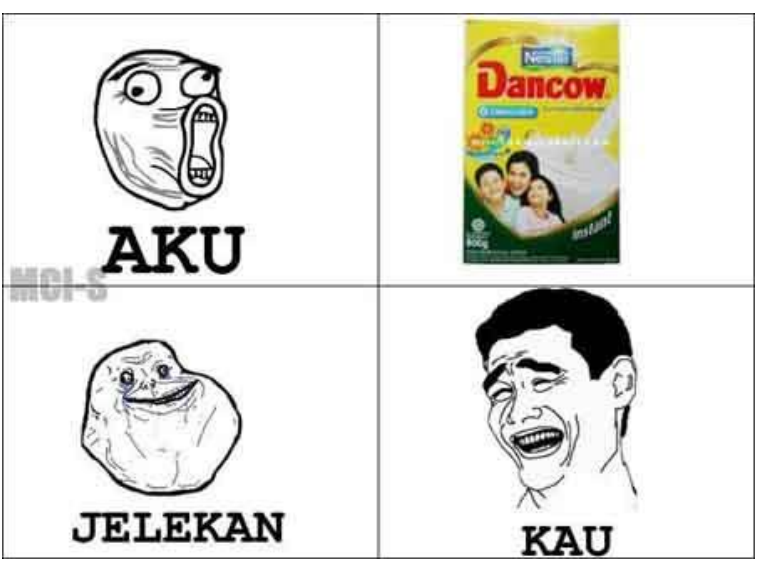

Gambar 2. Meme Komik dari laman Meme Comic Indonesia
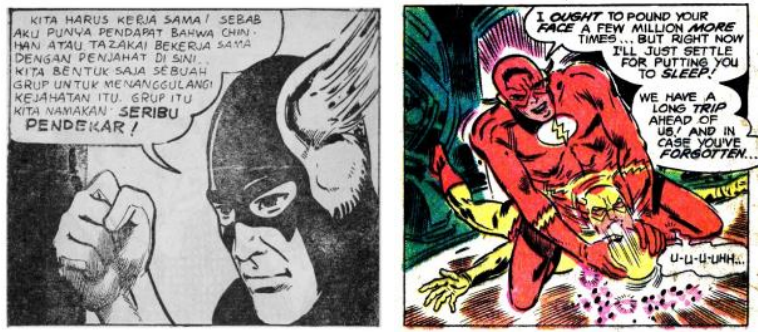

Gambar 3. Komik Gundala (kiri) karya Hasmi yang diduga memiliki kemiripan dengan karakter The Flash (kanan) milik DC Comics.

Media sosial kini menjadi tempat berkembangnya komikus-komikus besar angkatan baru ini. Namanama seperti Faza Meonk (Si Juki), Sweta Kartika (Nusantaranger, Grey \& Jingga, Wanara), dan Haryadhi (Kostum, Rixa, Setan Jalanan) yang memulai budaya komik strip online besar dari platform yang sama, Facebook. Para pekerja penting dan pemilik platform seperti Yudhanegara Njoman (editor dan publisher Comico, Re:On dan Caravan Studio), Borton Liew (mantan CEO Ciayo Comics), Tessa Y.P. (pemilik Kisai Entertainment), Is Yuniarto (Komikus Garudayana dan GM dari Bumi Langit Comics) juga bersosialisasi dengan komunitas kreator ini di Facebook. Penulis juga berkembang bersama dengan komunitas kreator di Facebook, rata-rata kreator Indonesia memang saling terhubung lewat Facebook. Maka bisa dibilang tidak mengherankan jika Facebook adalah media sosial yang menjadi pusat perkembangan dari komik Indonesia masa kini. Salah satu komik yang sedang popular di Facebook adalah Komik MS Paint Demi Kehidupan Beragama yang Tentram.

Komik MS Paint Demi Kehidupan Beragama yang Tentram adalah komik besutan Dhikara Dwinanda - atau biasa dipanggil Inan. Dia adalah seorang editor komik di Kisai Entertainment. Komik edisi perdananya tayang di Facebook pada tanggal 31 Maret 2017. Dalam satu setengah tahun, laman
Facebook Komik MS Paint sudah memiliki 15 ribu penggemar dan 16 ribu pengikut. Komik MS Paint digambar dengan warna hitam-putih, garis yang tidak rapi dan bentuk-bentuk yang tidak proporsional.

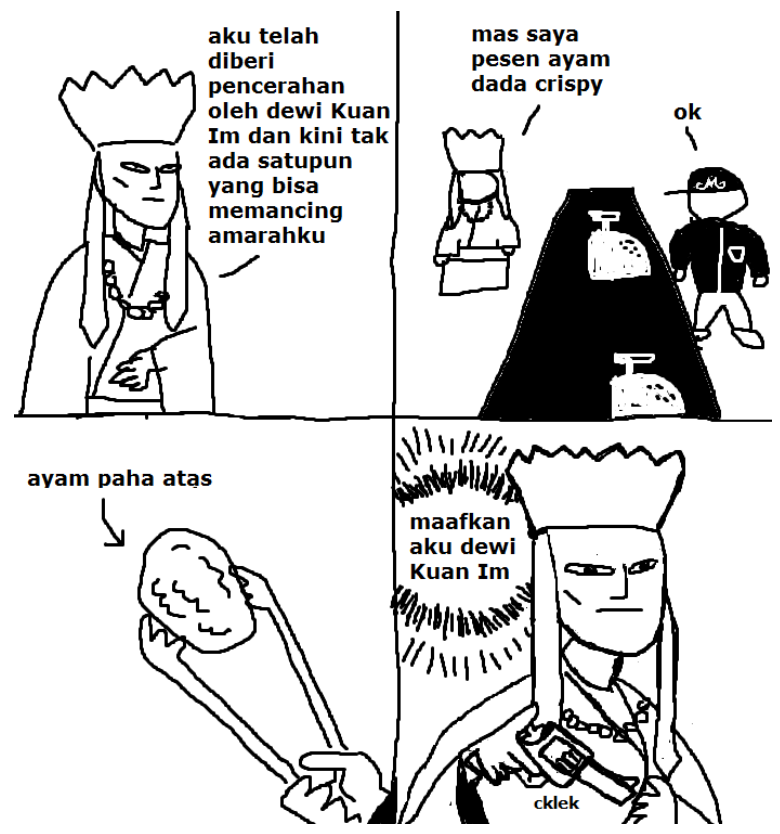

Gambar 4. Salah satu edisi terpopuler Komik MS Paint

Hal ini bertolak belakang dengan komik Indonesia yang baru-baru ini populer. Kebanyakan komik Indonesia masa kini berkiblat pada gaya Jepang dan Barat yang menampilkan kualitas seni yang tinggi akan craftsmanship. Sementara kualitas gambar dari Komik MS Paint yang cenderung berantakan seolah sarat akan muatan artistik. Hal ini memunculkan beberapa rumusan masalah mengenai apakah Komik MS Paint adalah seni komik, atau ia hanyalah sebuah meme komik? Jika ia adalah seni, mengapa Komik MS Paint menggunakan kualitas gambar yang terkesan sarat akan nilai artistik? Jika pun ia adalah seni, bagaimana Komik MS Paint membedakan diri dari meme komik?

\section{Pembahasan}

Untuk menjawab apakah Komik MS Paint adalah seni komik atau sekadar meme komik, kita perlu memahami tentang bagaimana sebuah objek dapat dikatakan sebagai meme serta kondisi apa saja yang harus terpenuhi untuk objek dapat dikatakan sebagai seni. Seni secara definisi pada objeknya ditentukan dari adanya upaya ekspresi emosi (Sunarto, 2009) dalam rangkaian garis, bentuk atau warna, suara atau kata yang ditata (Davies, 2003). Sementara itu, Meme, berasal dari teori yang diusulkan oleh Richard Dawkins yang sebenarnya adalah teori Biologi-walaupun sebenarnya berasal 
dari kata Mimesis, yang berarti meniru. Namun pada perkembangan zaman, Meme Internet juga muncul. Disebut Meme Internet memiliki ciri khas yang sama dengan Meme Biologi, yaitu mudah dibagikan, mudah ditiru dan mudah tersebar (Díaz, 2013). Dari sini dapat disimpulkan bahwa meme tidak dapat disebut sebagai seni, karena ia tidak memiliki bobot sebagai manifestasi ekspresi emosi walaupun ia dapat menjadi media komunikasi, baik visual, audio, dan lain-lain.

Kembali dalam konteks, penulis telah melakukan wawancara dengan narasumber (Inan) untuk memastikan bagaimana metode penciptaan dari Komik MS Paint. Inan menyatakan bahwa Komik MS Paint lahir karena kecemasannya pada kemungkinan untuk ia kehilangan tangan kanannya - yang mana adalah tangan dominannya. Jadi pada mulanya ia membuat komik ini dengan menggunakan tangan kirinya-yang membuat hasil gambarnya menjadi tidak proporsional (Dwinanda, 2018). Ini merupakan dasar argumen bahwa Komik MS Paint berangkat dari ekspresi akan ketakutan. Hal ini membuktikan bahwa di dalam konteks seni, Komik MS Paint sesungguhnya telah memenuhi syarat-syarat untuk disebut sebagai karya seni.

Namun di sisi lain, Komik MS Paint menghadirkan banyak meme dalam kontennya, namun dalam bentuk dan pesan yang lebih ironis. Seperti pada contoh gambar berikut adalah contoh Komik MS Paint yang mengadaptasi meme yang disebut dengan nama "Loss". Meme "Loss" bercerita tentang kegagalan janin dalam sebuah komik berjudul "Ctrl+Alt+Del". Namun tidak seperti biasanya, komik edisi "Loss" ini rupanya dianggap terlalu dramatis dan tidak lazim untuk muncul dari serial ini, sehingga ia menerima banyak ledekan online sehingga menjadi meme dengan pattern yang sama (Ltd, Literally Media, 2011).

Tidak hanya itu, Komik MS Paint juga menjadi meme itu sendiri, dalam arti ia tidak hanya mengadaptasi meme menjadi konten bagi dirinya, namun ia menjadi konten yang ditiru oleh komikkomik lainnya. Tentu hal ini menjadi problematik, karena selain ia memenuhi standar sebagai seni, Komik MS Paint juga memiliki konten yang menjadi meme. Sebagai contoh, komik edisi ke 47 dari Komik MS Paint ditirukan oleh Ghosty Comic (karya Raden Fajar Hadria Putra) yang memiliki tema kehidupan kolektor action figur yang sering kali tidak bisa menguasai pembelanjaan uangnya demi hobinya. Bahkan Ghosty Comic tidak hanya meniru pola ceritanya saja, namun ia juga meniru gaya gambarnya.

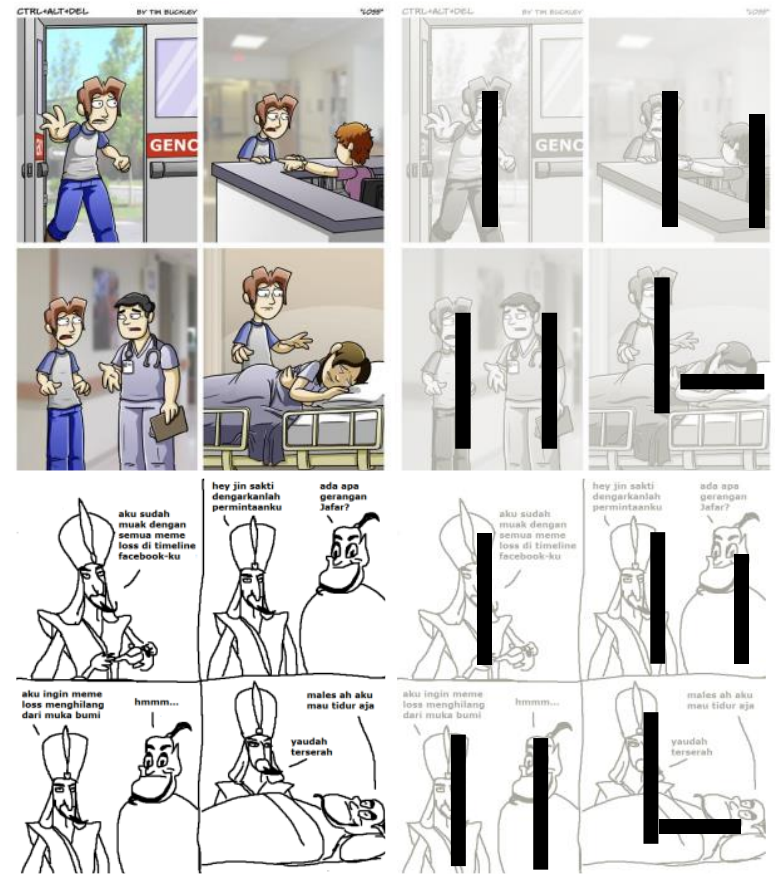

Gambar 5. Komik loss dan patternnya yang menjadi meme serta Komik MS Paint menampilkan pattern loss secara ironis.

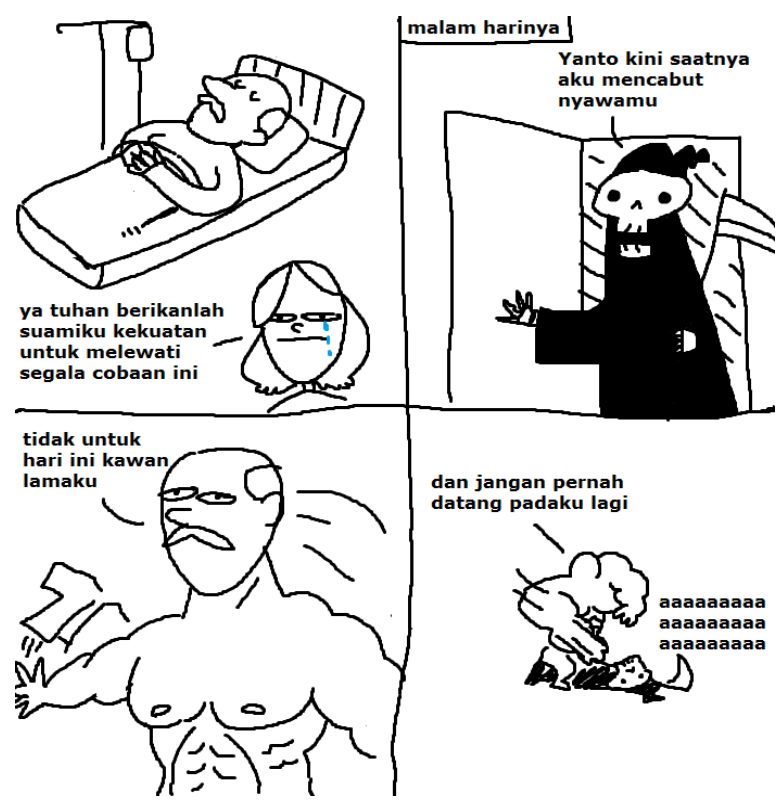

Gambar 6. Komik MS Paint Edisi 47 yang menjadi meme

Dalam banyaknya fakta yang muncul dari komik ini-bahwa komik ini memiliki kualitas untuk menjadi meme ataupun menjadi seni-, perlu kita telaah kembali tentang klasifikasi pembeda antara meme dan seni sehingga ia dapat dikategorikan ke dalam salah satu koridor ini. Misalnya fakta tentang adanya tiruan dari komik ini menarik sebuah benang merah bahwa keberadaan Komik MS Paint dapat dilihat dari kacamata posmodernisme dalam idiom pastiche. 

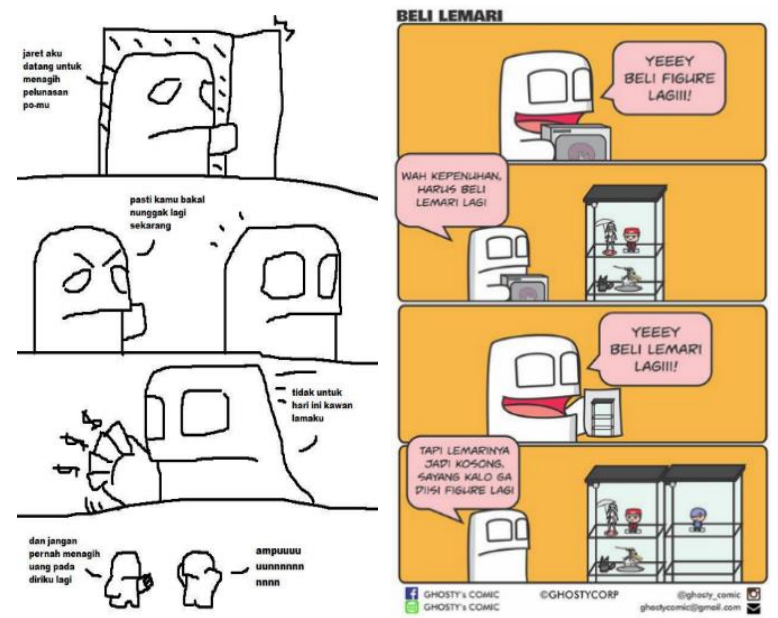

Gambar 7. Tiruan oleh Ghosty Comics serta bentuk asli dari Ghosty Comic, dapat dilihat bahwa tiruan ini benarbenar meniru sampai pada kualitas visual aslinya.

Pastiche memiliki karakteristik untuk meniru, mencari, menggali dan menonjolkan aspek-aspek dari masa lalu dengan memunculkannya kembali dalam sebuah objek baru. Berbeda dengan parodi, pastiche cenderung menampilkan persamaan karena pada hakekatnya, ia beroperasi sebagai apresiasi artistik bagi karya yang ia tiru (Piliang, 2003). Menerima apresiasi artistik berbeda dengan bagaimana meme juga ditiru dan disebarkan seperti pada kasus di atas karena meme bergerak sebagai parodi (Shifman, 2013). Meme beroperasi dengan meniru, sekaligus menciptakan kebalikan dari objek aslinya untuk menyampaikan sebuah pesan ketidakpuasan, atau humor ironis dan bahkan pos-ironis yang semata-mata hanya tercipta bukan untuk apresiasi. Maka Komik MS Paint dapat nyatakan sebagai sebuah karya seni. Namun demikian, masih ada hal yang perlu dibuktikan, karena saratnya kualitas artistik dari Komik MS Paint ini masih dapat dipertanyakan.

Kualitas artistik dari komik memang menjadi poin penting dalam menentukan sebuah karya layak untuk disebut karya seni atau tidak. Namun hal itu hanya terjadi dalam estetika zaman dahulu. Estetika era klasik, renaisans, bahkan modern masih menjunjung tinggi nilai-nilai artistik dengan rasio (Hauskeller, 2015). Seolah-olah semakin realistis dan sempurna, semakin layak lah ia disebut sebagai sebuah seni. Argumen penulis adalah bahwa karya Komik MS Paint justru menjadi pendobrak dari kesenian komik yang selama ini dinilai dari keindahan gambarnya saja. Ia berdiri diatas estetika postmodern idiom kitsch, yang seolah-olah bernilai sampah, namun memiliki nilai kritik. Di samping itu, Komik MS Paint memiliki kualitas storytelling yang tidak sembarangan ketika di bandingkan dengan meme.

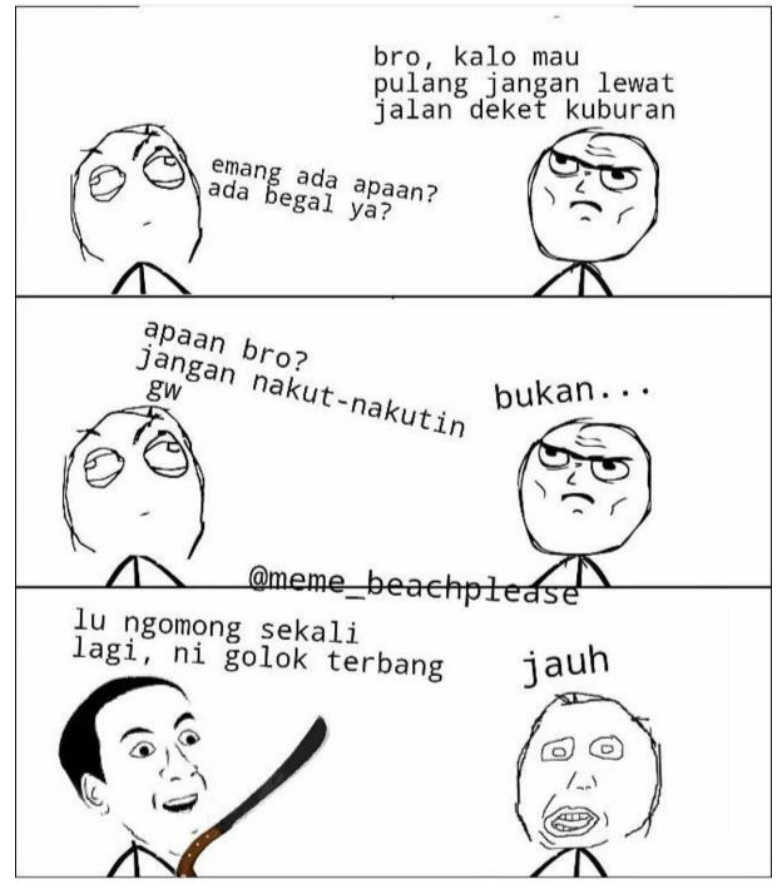

Gambar 8. Peletakan teks Meme Comic yang tidak memiliki kualitas storytelling yang baik

Inan, dalam wawancara menyatakan bahwa gaya gambar yang dia buat juga merupakan sebuah upaya untuk mencapai ironisme (Dwinanda, 2018). Kualitas gambar yang seolah tidak layak publikasi ini justru menjadi bukti bahwa dalam mencapai estetika masa kini, pendekatan yang berbedalah yang menjadi jawaban dari kurungan standarisasi komik bagus dari kacamata seni. Penulis menilai ini sebagai strategi yang tepat untuk menanggapi masyarakat yang haus akan kebaruan. Hal inipun menjawab mengapa Komik MS Paint ini berbeda dengan meme. Karena meme mungkin memiliki kualitas artistik ketika ia digarap oleh seorang artisan, namun meme tidak memiliki tujuan untuk mencapai kualitas artistik itu. Ia hanya bertujuan untuk hiburan dan cenderung anti apresiasi. Maka Komik MS Paint tidak hanya berbeda dari meme, namun juga terbukti memiliki kualitas sebagai seni ketika dilihat dari sudut pandang estetika postmodern.

\section{Simpulan}

Komik MS Paint dinilai oleh penulis sebagai sebuah karya yang memiliki nilai kebaruan dan patut disebut sebagai seni. Karena ia besar dari selera humor ironis dalam metode penciptaannya. Ia lahir dari ekspresi ketakutan, dan menertawakannya dalam bentuk yang kacau dan tidak proporsional. Ia datang dengan storytelling yang tidak sembarangan serta konsep yang baru dalam dunia perkomikan Indonesia. Bahkan ia dekat dengan pembacanya karena memiliki kaitan yang sangat 
erat dengan budaya meme internet, walaupun dapat dikatakan ia adalah sebuah seni, bukan meme. Sesungguhnya hal ini adalah bukti bahwa komik MS Paint memiliki strategi dalam menginfiltrasi dunia yang haus akan kebaruan. Ketika semua orang mencoba mengejar kesempurnaan, ia menjadikan sebuah karya yang terlihat murahan memiliki nilai yang lebih. Menonjolkan hal yang selama ini dianggap sampah (MS Paint) menjadi sebuah media bercerita yang dahsyat dan viral.

\section{Daftar Pustaka}

Davies, S. (2003). Definition of Art. Cornell University Press.

Díaz, C. M. (2013). Defining and characterizing the concept of Internet Meme. Revista CES Psicología , 83-104.

Hauskeller, M. (2015). Seni-Apa itu? Yogyakarta: Kanisius.
McCloud, S. (1993). Understanding Comics. New York: HarperPerennial.

Shifman, L. (2013). Memes in a Digital World: Reconciling with a Conceptual Troublemaker. Journal of Computer-Mediated Communication, Volume 18, Issue 3, 362-377.

Sunarto. (2009). Seni Sebagai Ekspresi Emosi (Telaah Hakiki dan Nilai Seni dalam Ekspresivisme). Imajinasi, Vol 5, No 1 .

Piliang, Y. A. (2003). Hipersemiotika: Tafsir Cultural Studies atas Matinya Makna. Yogyakarta: Jalasutra.

Ltd, Literally Media. (2011, Juli 2). Know Your Meme. Retrieved Oktober 18, 2018, from https://knowyourmeme.com/memes/loss

\section{Informan}

Dwinanda, D. (2018, Oktober 15). Wawancara Teori Seni. (Author, P) 